\title{
CLASSROOM INTERACTION STRATEGIES EMPLOYED BY ENGLISH TEACHERS AT LOWER SECONDARY SCHOOLS
}

\author{
Nunung Suryati \\ (nunung_suryati@yahoo.com) \\ Universitas Negeri Malang \\ Jl. Semarang 5, Malang 65145, Indonesia
}

\begin{abstract}
This article reports a study on teachers' use of interaction strategies in English Language Teaching (ELT) in lower secondary level of education. The study involved eighteen teachers from Lower Secondary Schools in Malang, East Java. Classroom observation was selected as a method in this study by utilizing Self Evaluation Teacher Talk (SETT) as the instrument. SETT, developed by Walsh (2006), was adopted as the observation protocol as it characterises teacher-student interaction. Thirty lessons taught by 18 teachers were observed. The findings revealed that much of the teacherstudent interaction in Lower Secondary Schools centred on the material mode, skill and system mode. The most frequent strategies were initiation response feedback (IRF) patterns, display questions, teacher echo, and extended teacher turns, while students' extended turns were rare. It is argued that in order to improve the Indonesian ELT, there is a need to provide an alternative to ELT classroom interaction. The article concludes by highlighting the importance of adopting some classroom interaction strategies that are more facilitative to students' oral communicative competence.
\end{abstract}

Keywords: classroom interaction, teacher-student interaction, interaction strategies, ELT in Lower Secondary School level in Indonesia, classroom observation studies.

DOI: http://dx.doi.org/10.15639/teflinjournal.v26i2/247-264

Improving students' oral communicative competence in English language is not easy in Indonesia because English is a foreign language and is not used in daily conversation in the community. That makes students' exposure to English 
limited and the classroom is usually the only place where English is spoken. When students listen to the teacher's instructions and explanations, when they express their views, answer questions and carry out activities, they are not only learning about the structure of the language but also they are learning how to use the language for communication. Where a target language is seldom used outside the classroom, input and language use in classroom interaction especially in teacher-student interaction and student-student interaction are vital.

Classroom interaction in an EFL context is defined as all communication which refers not only to those exchanges involving authentic communication but to every oral exchange that occurs in the classroom, including those that arise in the course of formal drilling (Ellis, 1990, p. 12). If effective classroom interaction strategies can be employed to enhance students' communicative competence, students' performance should increase.

For many years researchers have indicated the importance of effective classroom interaction strategies to promote student language development. For example, Kramsch (1986) suggests that to achieve students' communicative competence, students must be given opportunities to interact with both the teacher and fellow students through turn-taking, to receive feedback, to ask for clarification, and to initiate communication. Rivers (1987) argued that to promote effective classroom interaction, teachers should avoid dominating oneway talk, be cooperative, and consider students' affective variables.

Mackey (1999) suggests that teachers construct interactive learning environments where students can communicate with each other to generate meaning in the target language. In other words, teachers need to orchestrate classroom interaction that allows students' active participation to produce the target language through turn-taking, feedback, and negotiation.

In Indonesian context, an earlier study by Lewis (1997) looked at teacherstudent interaction in the secondary level. His findings revealed that English lessons were teacher-centred and textbook driven. The textbooks presented units following a structured syllabus with graded reading passages and dialogues. Teachers typically explained new grammatical structures and required students to memorize grammar rules and new vocabulary. Lessons were taken up with teacher talk. Students were tested on their translation of new vocabulary and understanding of grammar. Domination of teachers' talk in EFL classes is confirmed by Astika's study (1996) on Indonesian EFL classroom in primary schools. The researcher reported teachers' dominated classroom time. The classroom interaction consisted of $54.22 \%$ teachers' talk and only $14.9 \%$ 
students' talk, while the rest $30 \%$ was of silence and confusion. The researcher reported that students were mostly passive and did not respond to teachers' presentation, which, she argued, was because the students did not want to be considered arrogant as Javanese children are trained to be obedient to parents and teachers. Lestari (1999) suggested that teachers provide opportunities for students to use the language and make students speak in English by using games, songs and riddles as well as provide more feedback to correct students' mistakes.

Milal's (2011) study also reported on teacher domination of teacherstudent interaction. His findings indicated that teachers dominated the classroom discourse with 341 utterances; students produced only 104 individual utterances, and 31 choral responses. Among those teachers' utterances, 198 were directive acts which requested services such as instructing, nominating, commanding, ordering, requesting, stimulating, calling attention, asking for repetition, drilling, and correcting pronunciation. In addition to the directive acts, there were utterances which the teacher used in eliciting, asking, prompting, checking comprehension, checking knowledge, and asking for confirmation.

Other studies have also explored teachers' questioning ways in Indonesian EFL classrooms (Tulung, 2006; Rohmah, 2002; Arifin, 2012). For example, Tulung (2006) reported that teachers' questions were dominated by display questions. Rohmah (2002) confirmed Tulung's finding by describing that open questions inviting students to think aloud in generating sequences of thought and to explore implications were significantly fewer than closed ones. Display questions took place more than twice as many as referential questions. Most of the teachers' questions checked students' comprehension and required them to recall facts. Very few of them asked students to make inferences and judgements. The most common strategy that teachers use is to repeat questions (Rohmah, 2002). Arifin's findings (2012) on teacher questions in lower secondary school context were similar to Rohmah's and Tulung's findings. He reported that teachers used $66.7 \%$ of display questions and $33.3 \%$ referential questions. Students' responses were mostly verbal, consisting of a few words or simple sentences.

A recent study on teacher-student interaction conducted by Maulana, Opdenakker, Stroet, and Bosker (2012) revealed that Indonesian teachers spent most of their time lecturing in front of the classroom. There is hardly any interaction with students. Most teachers showed little awareness of their students' learning process and did not pay much attention to students' mistakes 
and misconceptions. The researchers highlighted that although Indonesian teachers have been given more autonomy in implementing more active teaching learning practices, many of them have not taken up this opportunity. The teachers' concerns were that implementing active teaching-learning practices might increase their workload because this approach demands more of teachers' time to prepare than whole class lecturing.

Studies which focused on pattern of interaction in Indonesian school settings were very rare but were plenty in non-Indonesian school contexts, for example, Hardman et al, (2003) conducted a study on classroom interaction in England, Abd Kadir \& Hardman (2007) and Wedin (2009) in Africa and Vaish (2008) in Singapore. These researchers found that the IRF (Initiation, Response, Feedback) pattern of teacher-student interaction dominated the classroom interaction and limited students' ability to contribute to classroom activities. This pattern of interaction did not achieve the communicative goals of English language instruction (Hardman et al., 2003; Abd Kadir \& Hardman, 2007; and Vaish, 2008).

As this review shows, examination of EFL classroom interaction at lower secondary level in Indonesia is still very limited. Therefore, this current research has been designed to add our understanding of EFL classroom interaction in Indonesia and its relation to students' communicative competence. More specifically, it aims to examine the interaction strategies teachers employ during the teacher-students interaction in their English class. The findings of study have the potential to improve the teaching of English to students at the lower secondary school level. With a better understanding of classroom interaction processes, teachers may improve the quality of their teaching and thereby improve students' learning.

\section{METHOD}

The researcher did direct observation without being a participant in the context. According to Creswell (2008), such a researcher is a "non-participant observer". Direct observation gives one the ability to stay "uninvolved" but still be present at the context in which action takes place (Trochim, 2001).

The researcher used video recording and audio recording as well as observational protocols to capture the classroom interaction for teacher-student interaction. There were two parts of the observation system. Part One describes when and where the observation took place. Part Two recorded the teacher- 
student interaction using the Self Evaluation of Teacher Talk (SETT) instrument developed by Walsh (2006). There were two sub-sections: the interaction structure and teacher-student interaction strategies.

SETT was used in the observation protocol to establish the structural format of the lesson. SETT consisted of four modes. The modes are related to the pedagogic goals in the classroom and the language that the teacher used to achieve them. Walsh (2006) defines mode as "an L2 classroom micro context that has a clearly defined pedagogic goal and distinctive interactional strategies determined largely by the teacher's use of the language" (Walsh, 2006, p.62). The four modes are managerial, material, skill and system and classroom context. The aim of managerial mode is to transmit information related to the management of the learning; material mode is to provide language practice around a specific piece of material; skill and system mode is to provide language practice in relation to particular language system or skills; and classroom context mode is to enable students to express feelings, experiences, attitudes and so on to promote oral fluency. Within the modes, there are 14 interaction strategies: scaffolding, direct repair, content feedback, extended wait time, referential questions, seeking clarification, extended learner turn, teacher echo, teacher interruption, extended teacher turn, turn completion, display questions, form focused feedback, and confirmation check.

The subjects of the study were eighteen teachers of Lower Secondary Schools in Malang, East Java. Those teachers were observed once or twice. After the final lesson observation of each teacher, the researcher reviewed her lesson observation notes and her comprehensive audio and video transcriptions. Of the total 30 lessons observed, all were fully transcribed. The data from the lesson transcripts involving teacher-student interaction were analyzed in two ways. The first level of analysis sought to identify time devoted to teacherstudent interaction and student-student interaction. The second level of analysis aimed to identify the modes, the frequency of interaction strategies used based on SETT framework.

\section{FINDINGS AND DISCUSSION}

\section{Findings}

This part describes the result of classroom observation by summarizing the observations of the lessons conducted by eighteen teachers in Lower Secondary 
Schools in Malang. Table 1 provides a summary of the teachers, total of lessons and topics of the lessons that were observed in the study.

Table 1. Summary of Lesson Observations at Lower Secondary Schools

\begin{tabular}{|c|c|c|c|}
\hline Teachers & $\begin{array}{l}\text { Total lesson } \\
\text { observed }\end{array}$ & Topic & $\begin{array}{l}\text { Grade } \\
\text { level }\end{array}$ \\
\hline$\overline{\mathrm{GE} 1}$ & 2 & $\begin{array}{l}\text { Reading: Sport } \\
\text { Speaking: Talking about Profession }\end{array}$ & $\begin{array}{l}\text { Eight } \\
\text { Eight }\end{array}$ \\
\hline GE2 & 1 & Reading: Unusual Hobbies & Eight \\
\hline GE3 & 2 & $\begin{array}{l}\text { Grammar: Adjective Clause } \\
\text { Reading: Narrative Text }\end{array}$ & $\begin{array}{l}\text { Nine } \\
\text { Nine }\end{array}$ \\
\hline GE4 & 2 & $\begin{array}{l}\text { Grammar: Tenses } \\
\text { Reading: Gardening }\end{array}$ & $\begin{array}{l}\text { Seven } \\
\text { Eight }\end{array}$ \\
\hline GE5 & 1 & $\begin{array}{l}\text { Singing \& Talking about a Song 'Nobody's } \\
\text { Child' }\end{array}$ & Eight \\
\hline GE6 & 1 & Reading: Narrative text & Seven \\
\hline GE7 & 2 & $\begin{array}{l}\text { Reading: Procedure Text } \\
\text { Grammar: Commands }\end{array}$ & $\begin{array}{l}\text { Seven } \\
\text { Seven }\end{array}$ \\
\hline GE8 & 2 & $\begin{array}{l}\text { Reading: Interesting places } \\
\text { Reading: Hercules }\end{array}$ & $\begin{array}{l}\text { Eight } \\
\text { Eight }\end{array}$ \\
\hline GE9 & 1 & Grammar: Past Continuous Tense & Seven \\
\hline GE10 & 2 & $\begin{array}{l}\text { Reading: Going to the Beach (Class A) } \\
\text { Reading: Going to the Beach (Class B) }\end{array}$ & $\begin{array}{l}\text { Eight } \\
\text { Eight }\end{array}$ \\
\hline GE11 & 2 & $\begin{array}{l}\text { Reading: Exciting Trip } \\
\text { Reading: Notice }\end{array}$ & $\begin{array}{l}\text { Nine } \\
\text { Nine }\end{array}$ \\
\hline GE12 & 2 & $\begin{array}{l}\text { Reading: Food } \\
\text { Reading: Narrative Text }\end{array}$ & $\begin{array}{l}\text { Eight } \\
\text { Eight }\end{array}$ \\
\hline GE13 & 2 & $\begin{array}{l}\text { Reading: The Weather (Class A) } \\
\text { Reading: The Weather (Class B) }\end{array}$ & $\begin{array}{l}\text { Eight } \\
\text { Eight }\end{array}$ \\
\hline GE14 & 2 & $\begin{array}{l}\text { Grammar: Tenses (Class A) } \\
\text { Grammar: Tenses (Class B) }\end{array}$ & $\begin{array}{l}\text { Seven } \\
\text { Seven }\end{array}$ \\
\hline GE15 & 2 & $\begin{array}{l}\text { Reading: Procedure Text } \\
\text { Reading: Weather Forecast }\end{array}$ & $\begin{array}{l}\text { Seven } \\
\text { Seven }\end{array}$ \\
\hline GE16 & 1 & Reading: Narrative Text & Seven \\
\hline
\end{tabular}


Suryati, An Investigation of Classroom Interaction 253

\begin{tabular}{llll}
\hline Teachers & $\begin{array}{l}\text { Total lesson } \\
\text { observed }\end{array}$ & Topic & $\begin{array}{l}\text { Grade } \\
\text { level }\end{array}$ \\
\hline GE17 & 1 & Reading: Narrative Text & Seven \\
GE18 & 2 & Reading: Invitation & Eight \\
Total & 30 lessons & Writing: Short Messages & Eight \\
\hline
\end{tabular}

The most observed grade level was grade level $8(50 \%)$, followed by grade level 7 (37\%) and grade level 9 (13\%). Most of the lessons focused on reading $(70 \%)$, followed by grammar $(20 \%)$, listening \& speaking $(6.7 \%)$ and writing $(3.3 \%)$.

\section{Classroom Organization}

Two main types of classroom structures appeared in the observations: teacher fronted interaction and student-student interactions. The teacher fronted interaction is an interaction where the teacher worked with the whole class and typically interacted with a succession of individuals, while expecting the attention of the rest of the class. This interaction is initiated and controlled by the teacher, referred to as teacher-student interaction (T-S). The second form involved interaction among students when they were working in pairs or in a group. This type of interaction is labeled as student-student interaction (S-S). Table 2 shows the time spent on types of participation at Lower Secondary Schools.

Table 2. Time spent on Teacher-Class and Student-Student Interaction at Lower Secondary Schools

\begin{tabular}{llcc}
\hline $\begin{array}{c}\text { Time spent on type of } \\
\text { interaction }\end{array}$ & $\begin{array}{c}\text { Minutes } \\
\mathbf{( 3 0} \text { lessons) }\end{array}$ & $\mathbf{\%}$ \\
\hline & Total teaching time & 2400 & \\
1. & Time spent on T-S & 2232 & 93 \\
2. & Time spent on S-S & 168 & 7 \\
\hline
\end{tabular}


Table 2 indicates that the dominant type of interaction is teacher-student interaction. Teacher-student interaction occupied $93 \%$ of the time while the S-S interaction occupied only $7 \%$ of the time.

\section{Interaction Strategies Used by Teachers during Teacher-Student Interaction}

Interaction strategies and their frequency of occurrences in each mode in the observed lessons can be seen in Table 3 .

Table 3. Strategies Used by Teachers During Teacher-Student Interaction

\begin{tabular}{|c|c|c|c|}
\hline $\begin{array}{c}\text { Mode and } \\
\text { Pedagogic Goals }\end{array}$ & Interactional Strategies & Frequency & $\%$ \\
\hline \multirow[t]{2}{*}{ Managerial } & $\begin{array}{l}\text { A single, extended teacher turn which } \\
\text { uses explanations and/or instructions }\end{array}$ & 136 & 7.3 \\
\hline & $\begin{array}{l}\text { Negotiation (clarification request and } \\
\text { confirmation checks) }\end{array}$ & 0 & 0 \\
\hline \multirow[t]{6}{*}{ Materials } & *IRF /Non IRF patterns & $308 / 48$ & \\
\hline & Display /Referential Questions & $336 / 81$ & $18 / 4.3$ \\
\hline & Scaffolding & 14 & 0.9 \\
\hline & Form-focused feedback & 59 & 3.8 \\
\hline & $\begin{array}{l}\text { Negotiation (clarification request and } \\
\text { confirmation checks) }\end{array}$ & 14 & 0.7 \\
\hline & Direct repair & 12 & 0.6 \\
\hline \multirow[t]{8}{*}{ Skill and systems } & *IRF/Non IRF Pattern & $321 / 51$ & \\
\hline & Display / Referential Questions & $368 / 0$ & 20 \\
\hline & Scaffolding & 18 & 0.9 \\
\hline & Extended teacher turns & 346 & 18.7 \\
\hline & $\begin{array}{l}\text { Teacher's echo/ completion/ } \\
\text { interruption }\end{array}$ & $321 / 0 / 8$ & 17.3 \\
\hline & Form focused feedback & 77 & 4.1 \\
\hline & $\begin{array}{l}\text { Negotiation (clarification request and } \\
\text { confirmation checks) }\end{array}$ & 16 & 0.8 \\
\hline & Direct repair & 9 & 0.5 \\
\hline \multirow[t]{5}{*}{ Classroom context } & Extended learner turn & 22 & 1.2 \\
\hline & Short teacher turn & 4 & 0.2 \\
\hline & Direct repair & 4 & 0.2 \\
\hline & Content feedback & 0 & 0 \\
\hline & Referential questions & 6 & 0.3 \\
\hline
\end{tabular}


Suryati, An Investigation of Classroom Interaction 255

\begin{tabular}{llcc}
\hline $\begin{array}{c}\text { Mode and } \\
\text { Pedagogic Goals }\end{array}$ & \multicolumn{1}{c}{ Interactional Strategies } & Frequency & $\%$ \\
\hline & Scaffolding & 0 & 0 \\
\cline { 2 - 4 } & $\begin{array}{l}\text { Negotiation (clarification request and } \\
\text { confirmation checks) }\end{array}$ & 0 & 0 \\
\hline & \multicolumn{2}{c}{ Total } & 1851 \\
\hline
\end{tabular}

*Notes:

- The IRF/non IRF patterns are not added to the total number of teacher talk because they have been counted already in display/referential questions.

- IRF stands for Initiation Response Feedback

The data presented in Table 3 show that in Managerial mode, extended teacher turns in which teachers provided explanations and/or instructions in the beginning of the lessons constituted $7.3 \%$ of the teachers' talk. All teachers seemed to be comfortable talking about aspects of management in their classroom as evidenced by the amount of teacher talk that occurred. Teachers were transmitting information, introducing activities, organising the environment, and referring students to materials, but clarification request and confirmation checks in managerial mode were not found.

Materials mode appeared to be popular as the majority of teachers' talk revolved around the materials the students were using. The majority of students' materials were reading texts. Much of the interaction demonstrated the IRF (Initiation, Response, Feedback) pattern (Sinclair and Coulthard, 1975, 1992). The total IRF pattern identified was 308. Students' responses were evaluated immediately.

There was an extensive use of display questions. Display questions are questions to which the teacher knows the answer. The occurrence of display questions was $18 \%$. Compared to display questions, referential questions were less popular. Referential questions are questions in which the teacher does not know the answers. The occurrence of referential questions was $4.3 \%$.

Form focused feedback is feedback that focuses on word usage rather than the message itself. The occurrence of form focused feedback was 3.8\%. Form focused feedback offered by the teachers tended to be accompanied by an explanation generally given in L1. Most of the explicit corrective feedback focused on grammatical errors, such as the use of tenses, sentence structures, and vocabulary items. The following excerpt is an example of this: 


\section{Excerpt 1 (GE1, Talking about profession)}

T: What is the definition of a teacher, Natasya?

S: A teacher is someone who teach.

$\mathrm{T}$ : Kalau satu orang, jangan lupa kata kerjanya di tambah s/es. [if the subject is singular, don't forget to add s/es to the verb].

S: A teacher is someone who teach eh.. teaches.

Scaffoldings were rare in material mode. Walsh (2006) maintains that scaffolding which involves the 'feeding in' of essential language as it is needed plays an important part in assisting learners to express themselves and acquire new language. In the data, the occurrence of scaffolding was $0.9 \%$ Below is an example of scaffolding taken from the lesson observed. In this example, the teacher extended the student's answer by giving a clue.

\section{Excerpt 2 (GE1, Talking about profession)}

T: Aziz wants to be a lecturer. What is the definition of a lecturer, Azis?

S: someone who teaches ...

$\mathrm{T}$ : Is it in primary school or in university?

$\mathrm{S}$ : in university.

T: Ok. Are you ready to face university students?

S: Yes.

Negotiation moves (clarification requests and confirmation checks) are valuable in promoting opportunities for learning since they 'compel' learners to reformulate their contribution by rephrasing or paraphrasing. When learners clarify a contribution it is central to the acquisition process (Long, 1996). Although negotiation moves are vital, they were not common in the schools. There was only $0.7 \%$ of negotiation moves.

Direct repair, which involves a short and quick correction, is a useful interactional strategy since it has minimal effect on the exchange structure. This strategy was not common. There was $0.6 \%$ of occurrence of direct repair. The excerpt below demonstrates how the teacher repaired incorrect pronunciation of the word 'discusses':

\section{Excerpt 3 ((GE11, Reading: Interesting Places)}

$\mathrm{T}$ : What does the text mainly discuss?

S1: The text mainly discosses the writer's experience in Europe.

$\mathrm{T}$ : discusses

S1: The text mainly discusses the writer's experience in Europe 
In the skills and system mode, pedagogic goals are focused on providing language practice in relation to a particular language system (phonology, grammar, vocabulary, discourse) or language skill (reading, listening, writing and speaking). Pedagogic goals are oriented towards accuracy rather than fluency. The intention is to get the learners produce strings of accurate linguistic forms and to manipulate the target language (Walsh, 2006, p.74).

In this study, the data in Table 3 show that IRF pattern and display questions were dominant. In General schools, there were 321 IRF patterns, and the occurrence of display questions was $20 \%$. The IRF interaction and the display questions were mainly focused on grammar used in the reading texts, followed by vocabulary or other exercises related to the texts. The exercises were normally already available and printed in the students' book. The occurrence of a Non IRF pattern in this mode is not common: only 51 are identified. A non IRF pattern occurs in this mode particularly happened when teachers asked follow up questions, asking students to revise their responses.

Another common feature in the skills and system mode was extended teacher turns. They were used to establish the extent of students' knowledge and were demonstrated throughout this mode. The percentage of occurrence of the extended teacher turns was $18.7 \%$. Excerpt 4 is an example of an extended teacher's turn which functioned to strengthen students' knowledge of the past form of verbs and how to read them:

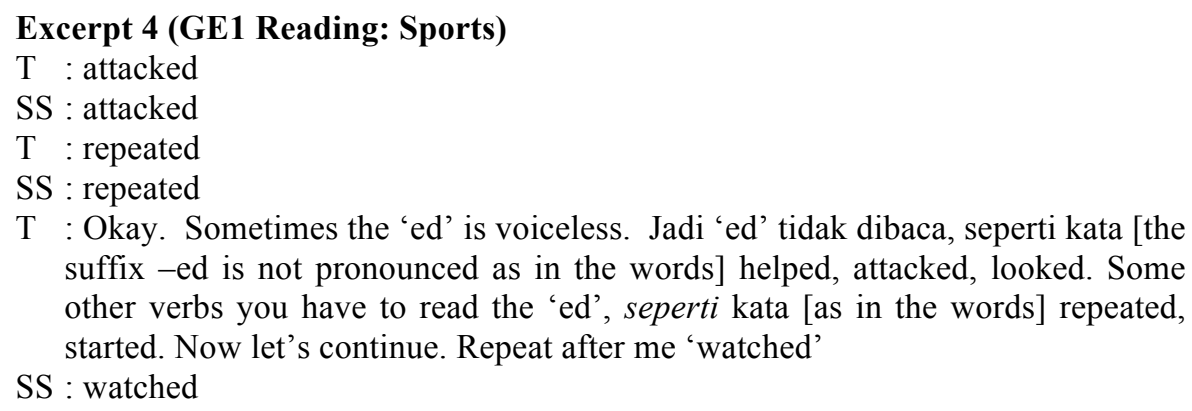
suffix -ed is not pronounced as in the words] helped, attacked, looked. Some other verbs you have to read the 'ed', seperti kata [as in the words] repeated, started. Now let's continue. Repeat after me 'watched'

SS : watched

The next feature in the skills and system mode was teacher echo which is used to display students' contribution by repeating it. The percentage of occurrence of the teacher echo was $17.3 \%$. Form focused feedback was demonstrated in the observed lessons, although not frequent in the skill and system mode. 
The total form focused feedback was $4.1 \%$. Most of the form focused feedback was on tenses or S-V agreement as in Excerpt 5.

\section{Excerpt 5 (GE17, Reading Narrative Text)}

T: Okay, your turn.

S: The prince fell sad after Cinderella left the party.

T: Fell? Bentuk kedua dari feel itu [the past tense of the word "feel" is] felt. Kalau fell bentuk pertamanya fall [the present form of "fell" is "fall"), fall- fell-fallen artinya jatuh. Ayo diperbaiki [Please fix it].

S: The Prince felt sad after Cinderella left the party.

Scaffolding, direct repair, and negotiation moves were not common in the skill and system mode. The total amount of scaffolding was only $0.9 \%$, direct repair was $0.5 \%$, and negotiation moves were $0.8 \%$.

In classroom context mode the pedagogic goal is to give opportunities for students to personalise the lessons by talking about their feelings or their experiences. This mode was not demonstrated in the current data. The focus of this mode is students' language production. The total percentage of student extended turns was $1.2 \%$. Only a few student extended turns were identified, demonstrating the rarity of this classroom context mode. It can be concluded that extended learners' turn, direct repair, content feedback, referential questions, clarification requests, and confirmation checks are rare in lower secondary EFL lessons observed.

Excerpt 6 is one of a few which demonstrated this mode. A student was assigned to speak in front of the class. He was given an opportunity to personalise the lesson by talking about his experience of visiting a favourite place because the topic of the reading text was 'Interesting Places':

\section{Excerpt 6 (GE8, Reading: Interesting Places)}

S: I like Balekambang Beach in Malang. Many tourism ...

T: tourists

S: Many tourists like to go to there.

S: The sand is very white and the wave is very wavy.

T: very big.

$\mathrm{S}$ : yes very big. We can do many things in Balekambang Beach, for examples sun-bathing, surfing or taking pictures.

T: Okay, thank you. Give applause for Adit. Any questions?

SS:No. 
It can be concluded that much of the teacher-student interaction in General Lower Secondary Schools centred on the material mode and skill and system mode. The most frequent strategies were IRF patterns, display questions, teacher echo, and extended teacher turns. Form focused feedback was also demonstrated although not frequently. Scaffolding and negotiation moves were rare. The classroom context was not apparent. Students were not given the opportunity to practise oral language production to personalise information or to connect their learning to their own experiences.

\section{Discussion}

Classroom observations have revealed that some strategies are used more frequently than others. IRF (Initiation Response Feedback) patterns and display questions, extended teacher turns, and teacher echoes were observed frequently in English lessons. Form-focused feedback was employed by teachers although this did not occur often. Other strategies including scaffolding, content-focused feedback, clarification requests, referential questions and extended students' turn were found to rarely occur.

Most teachers used a combination of reading text and grammar lessons. For example, teachers would start with a question and answer session about the topic of the reading then would ask students to read the text, followed by comprehension questions. Then students would be asked to complete grammar exercises. These activities were conducted in teacher-student interaction format. Only a few teachers provided communicative tasks for student-student interaction.

The focus of the lessons is students' comprehension of various text types and mastery of grammar. Most of the IRF patterns and display questions required student responses about vocabulary in the text and their understanding of the text. The prevalence of the IRF patterns in lower secondary classrooms is similar to findings of international researchers including Hardman et al. (2003), Abd-Kadir \& Hardman (2007), Vaish (2008), and Wedin (2009). The dominance of teachers' display questions confirms the findings by Rohmah (2002), Tulung (2006), and Arifin (2012).

The over-emphasis on IRF patterns, display questions, extended teacher turns, and teacher echoes does not support the development of students' communicative competence because there is little opportunity for students to use English in classroom interaction. Students are allowed to give very limited re- 
sponses to questions from teachers. There is no space for students to give responses in English that generate extended sequences of thought. Overall, there are limited opportunities for students to produce the language to promote their communicative competence in oral English. It was noted that the interaction strategies were employed without considering giving these opportunities sufficiently.

A combination of managerial, materials, and system and skills modes was a common practice in General Lower Secondary Schools, as demonstrated in Table 3. The classroom context mode which is designed to enable students to express themselves in target language for fluency is very limited. Consequently, the interaction strategies of this mode, that is, extended learner turn, short teacher turn, minimal repair, content feedback, referential questions, scaffolding, and clarification requests, were rarely observed. Only a few teachers implemented this mode in their teaching, and students have few opportunities to exercise their target language in an elaborated way.

The limited occurrence of classroom context mode may suggest that teachers do not know how to sequence lessons and manage classroom talk by employing appropriate interaction strategies. This finding echoes Howard's (2010) study, that classroom context mode is not exercised fully by teachers.

To maximize students' language production during the material and system and skill modes, Non-IRF (Modify F-move) patterns should be employed. During a discussion about a model of a communication act or a reading text, a common exchange is referred to the Initiation-Response-Feedback (IRF) sequence (Sinclair and Coulthard, 1975, 1992). The IRF routine may not be particularly useful for students' learning because it is a convergent process seeking one right answer. Scholars (e.g., Nassaji \& Wells, 2000; Cullen, 2002) have recommended that teachers manipulate the third component of such exchanges (Feedback turn). Teachers can do more than praising or evaluating the student's response. They can extend the Feedback part into additional questions that prompt students to elaborate (expand their responses), justify or clarify their opinions, and make connections to their experience. Such manipulation can achieve a variety of goals: it can clarify, connect, and elaborate the verbal interactions between teacher and students.

Moreover, teachers are also recommended to employ more referential questions in order to elicit sequences of thought from their students. Teachers should help students to elaborate their ideas into full sentences with correct structure and terms through scaffolding students' responses by reformulation 
(rephrasing students' contribution), extension (extending students' contribution), and modelling (giving a model for students' contribution) (Walsh, 2006, p.67). Teachers also need to pay attention to students' unclear utterances and use appropriate negotiation moves. For instance, teachers can use negotiation strategies: asking for clarification (I beg your pardon?), asking for confirmation (Do you mean .....?), and asking for repetition (Could you repeat that .....?) so that students are given opportunities to modify their utterances.

Finally, teachers should give more time for the classroom context mode which is designed to enable students to express themselves develop their oral fluency. The interaction strategies of this mode, that is, extended learner turn, short teacher turn, minimal repair, content feedback, referential questions, scaffolding, and clarification requests, can be exercised. Therefore, students have more opportunities to exercise their target language in a more elaborate way.

\section{CONCLUSIONS AND SUGGESTIONS}

The findings show that teachers spent $93 \%$ of their teaching time for teacher-student interaction and $7 \%$ for student-student interaction. During teacher-student interaction, the most popular interaction strategies are asking display questions (38\%), teacher extended turns (27.2\%), teacher echoes $(17.3 \%)$, giving form-focused feedback $(7.9 \%)$. The IRF patterns dominate teacher-student interaction as there are 629 IRF patterns altogether while nonIRF patterns only consist of 99 occurrences.

It can be concluded that teachers dominate the classroom interaction. They favour interaction strategies such as teachers' extended turn, asking display questions, echoing students' answers or their own statements, and giving formfocused feedback although they did not occur very often and employed IRF format. As a result students had limited opportunities to participate in teacherstudent interaction and to practice speaking English in class. Moreover, interaction strategies such as extended learner turn, short teacher turn, minimal repair, content feedback, referential questions, scaffolding, and clarification requests were rarely observed; consequently, students had little opportunities to exercise their oral English in an elaborate way.

To maximise students' opportunity to participate in effective classroom interaction, and thereby improve their oral communicative competence, it is suggested that existing approaches to teacher-student interaction be reconfigured. Providing and adopting classroom interaction strategies that are more facilita- 
tive to enhance the students' oral communicative competence should also be considered by Indonesian ELT practitioners. Future researchers are recommended to investigate the effectiveness of these facilitative classroom interaction strategies in promoting students' oral competence.

\section{REFERENCES}

Abd - Kadir, J. \& Hardman, F. (2007). The discourse of whole class teaching: A comparative study of Kenyan and Nigerian primary English lessons. Language and Education, 21(1), 1-15

Arifin, T. (2012). Analysing English as a foreign language (EFL) classroom interaction. Apple3L Journal, 1(1), 1-20.

Astika, G. (1996, March). Teaching-learning processes in English classes in some primary schools in Central Java and Yogyakarta. Paper presented in Teflin Regional Seminar 11, Surakarta, Central Java.

Creswell, J. W. (2008). Educational research: Planning,conducting, and evaluating quantitative and qualitative research. New Jersey: Pearson Prentice Hall.

Cullen, R. (2002). Supportive teacher talk: the importance of the F-move. ELT Journal, 56(2), 117-127.

Ellis, R. (1990). Instructed second language acquisition: Learning in the classroom. Oxford: Basil Blackwell Ltd.

Gass, S. \& Mackey, A. (2007). Data elicitation for second and foreign language research. Mahwah, N.J: Lawrence Erlbaum Associates

Hardman, F., Smith, F., Wall, K. (2003). Interactive whole class teaching in the national literacy strategy. Cambridge Journal of Education, 33(2), 197215 .

Howard, A. (2010). Is there such a thing as a typical language lesson? Classroom Discourse, 1(1), 82-100.

Kramsch, C. J. (1986). From language proficiency to interactional competence. The Modern Language Journal, 70(4), 366-372. 
Lestari, L.A (1999). English classroom culture reformation: How can it be done? TEFLIN Journal, 10(2), 75-87.

Lewis, R. (1997). Indonesian students' learning styles. EA Journal, 14(2), 2732.

Mackey, A. (1999). Input, interaction and second language development: An empirical study of question. Studies in Second Language Acquistion, 21(4), 557-587.

Maulana, R., Opdenakker, M. C., Stroet, K., \& Bosker, R. (2012). Observed lesson structure during the first year of secondary education: Exploration of change and link with academic engagement. Teaching and Teacher Education, 28(6), 835-850.

Milal, A. D. (2011). Indicators of practice of power in language classrooms. TEFLIN Journal, 22(1), 1-15.

Nassaji, H., \& Wells, G. (2000). What's the use of 'Triadic Dialogue'?: An investigation of teacher-student Interaction. Applied Linguistics, 21(3), 376406

Rivers, M. (1987). Interaction as the key to teaching language for communication. In W. M. Rivers, (Ed.), Interactive language teaching (pp. 3-16). Cambridge: Cambridge University Press.

Rohmah, Z. (2002). Teacher's questions in reading class. TEFLIN Journal, 13(2), 163-174.

Sinclair, J. M. \& Coulhard, R. M. (1975). Towards an analysis of discourse: The English used by teachers and pupils. London: Oxford University Press.

Sinclair, J. M. \& Coulhard, R. M. (1992). Towards an analysis of discourse. In M. Coulthard (Eds.), Advances in spoken discourse analysis (pp. 1-34). London: Routledge.

Trochim, W. M. K. (2001). Research methods knowledge base. Cincinnati, $\mathrm{OH}$ : Atomic Dog Publishing.

Tulung, G. J. (2004). Teacher managing a task within task-based instruction: A case study in an EFL setting. In B.Y. Cahyono \& U.Widiati (Eds.), The 
264 TEFLIN Journal, Volume 26, Number 2, July 2015

tapestry of English language teaching and learning in Indonesia (pp.143156). Malang: State University of Malang Press.

Vaish, V. (2008). Interactional patterns in Singapore's English classrooms. Linguistics and Education, 19(4), 366-377.

Walsh, S. (2006). Exploring classroom discourse: Language in action. London: Routledge.

Wedin, A. (2009). Classroom interaction: Potential or problem? The case of Karagwe. International Journal of Educational Development, 30(2), 145150. 